International Journal of English Language Studies (IJELS)

ISSN: 2707-7578

DOI: $10.32996 /$ ijels

Website: https://al-kindipublisher.com/index.php/ijels

\title{
Can get passive replace be passive in English?
}

\author{
Yunita Reny Bani Bili 8 (D) \\ Universitas Nusa Cendana, Kupang, Indonesia \\ Corresponding Author: Yunita Reny Bani Bili, E-mail: yunita.bili@staf.undana.ac.id
}

\begin{tabular}{l} 
ARTICLE INFORMATION \\
Received: May 04, 2021 \\
Accepted: June 12, 2021 \\
Volume: 3 \\
Issue: 6 \\
DOI: $10.32996 /$ ijels.2021.3.6.5 \\
\hline KEYWORDS
\end{tabular}

Get passive, be passive, semantic structure, meaning, use

\section{ABSTRACT}

While some traditional grammarians claim that get passive is the alternative colloquial of be passive, some scholars argue that get passive cannot be used to replace be passive since the use of get as a passive auxiliary is very limited. Due to the debatable claims, this research paper investigated whether be passive can replace get passive or not. In finding the answer, the writing was done by a thorough library study about semantic structure and division of each passive's role. The result shows that get passive cannot replace be passive because of several reasons. From a semantic structure point of view, firstly the stative verbs, such as emotion and thought cannot be addressed with get passive. Secondly, get passive does not go well with the verbs "creation". Following the structure, it is important to note that be passive and get passive have distinctive roles according to the event. Six types of get passives support this claim because get passive shows no indication that it can replace the function of be passive in some contexts. The types of get passive covers non-reflexive adversative, reflexive adversative, adversative get passive with an inanimate subject, beneficial get passive, the reflexive beneficial get passive and the beneficial get passive with an inanimate subject. After proposing all these different uses of get passive, it can be argued that get passive cannot be claimed to replace be passive because it denotes different meanings and get passive has restricted uses. If be passive is used in the context of get passive then it will shift the meanings.

\section{Introduction}

The term active and passive voice has been studied for ages by many linguistics scholars. To have a clear-cut definition of these terms, it is important to understand the definition. Pence and Emery defined this term as:

"Voice is that property of a verb which makes clear whether the subject of the verb performs the action or received the action described by the verb. If the subject performs the action (or is in the state or condition), described by the verb, the verb is said to be in the active voice. If the subject receives the action, the verb is said to be in the passive voice (...). The passive voice employs the auxiliary verb be combined, in any of its forms, with the past participle of the notional verb."(cited in Granger 1983: 3)

The definition clearly figures out that the basic distinction of active and passive constructions lies in the role of the subject whether as a performer or a receiver of an event. Despite the role of a subject as a performer, this research paper focuses on the role of a subject who receives the action or so-called passive voice. This writing specifically looks at the use of be passive and get passive in English. The idea of comparing the use of these types of passive arose from the claim of traditional grammarians who treat get passive as the inelegant and colloquial use, meaning that get passive is the alternative colloquial of be passive (Hatcher cited in Chappel 1980: 416). The term be + past participle is predominantly used to construct passive sentences rather than get passive informal style (Leech\& Svartvik cited in Granger: 192). Svartvik pointed out the use of this form is around $64,6 \%$ but get passive is only $17 \%$ (cited in Granger 1983: 195).

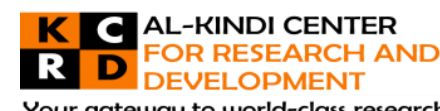

Your gateway to world-class research

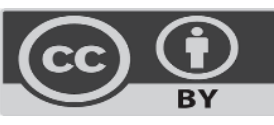

Published by Al-Kindi Center for Research and Development. Copyright (c) the author(s). This open access article is distributed under a Creative Commons Attribution (CC-BY) 4.0 license 
Conversely to this claim, Hatcher's article argues that get cannot be used to replace be since the use of get as a passive auxiliary is very limited (Hatcher cited in Chappel 1980: 416). She, moreover, argues that get can only be used for the fortunate or unfortunate consequences of the sentence's subject (Hatcher cited in Chappel 1980: 416). Regarding Hatcher's argument, Lakoff points out a similar view that the use of English get-passive is different from be-passive because get-passive is regularly used to mirror a speaker's attitude about an event. The attitudes are related to the speaker's evaluation and feeling about the event whether it is good or bad for him (Lakoff cited in Chappel 1980: 416).

Another important argument from Hatcher and Lakoff is the responsibility of the subject which more refers to the active involvement of the subject. Both scholars made a clear distinction that the subject plays more control in determining the result of an event in the get-passive, but the subject is totally an undergoer or a receiver in the be-passive.

Due to these debatable claims, this research paper investigated whether be passive can replace get passive or not. In finding the answer, the writing was done by firstly looking at the semantic structure of the get passive and be passive. This is done to recognize the similarity and differences of each passive's structure. Following this structure, the inchoative uses of get are also figured out to provide a clear understanding of distinguishing a form of get passive and participial adjective. The last point of this writing describes six types of get passives to answer the title question. This research paper argues that get passive is not the inelegant alternative to be passive and get passive cannot replace be passive because it has different and restricted semantic meaning and uses from be passive.

\section{Methodology}

This paper employed the qualitative research method to seek the answers to the research question. In finding the answer, a library study was conducted as an approach to support the claim and gather the evidence. The data was collected from secondary sources, namely journals related to get passive and be passive. Several previous studies from scholars such as Jespersen and Cume (cited in Hatcher 1949), Chappell (1980), Chomsky (cited in Culicover 2009), Börjars and Burridge (2010), etcetera were reviewed and investigated to explain each passive type according to its semantic structures and roles.

\section{Discussion}

As the first step of this investigation, it is important to look at two semantic structures of get passive to differentiate it with be passive. The essential thing of the first structure is the stative verbs, such as emotion and thought cannot be used with get passive. In other words, it is incorrect to say the decision got preferred, instead, it should be the decision was preferred. Jespersen and Curme (cited in Hatcher 1949: 434) have a similar view that get passive is only restricted to action verbs rather than stative verbs. The other point of this structure is get cannot be used with the verbs which signify the unplanned alteration of inanimate subjects (Chappell 1980:421). For example, it is correct to say the fence was broken rather than the fence get broken.

The second semantic structure of get passive is a specific image of a subject that should be thought of by the speaker before an event involving the subjects can be predicated. Get passive does not go well with the verbs "creation", such as a baby was born on Christmas eve (Chappell 1980: 422). In this example, be passive is rather used than get passive because a baby cannot be created. The other argument which strengthens this claim is get passive cannot be used with an unspecific subject (Chappell 1980: 422). For example, the president was elected yesterday. Be passive is better used in this sentence because the subject does not refer to the president of a specific country. However, it might be grammatical to use get passive if the sentence in such this construction: the president of United States got elected yesterday.

Despite the differences, both passives have a similarity. The external agent of an event in the get passive can be implicitly or explicitly expressed in the sentence using by-phrase (Chappell 1980: 420). For example, the baby got injected by the doctor. Chomsky (cited in Culicover 2009: 186) also points out the similarity, in which an agentive by the phrase is also used in the be passive. Börjars and Burridge (2010: 89) also support Chomsky and Chappell's claims by arguing that the agentive by phrase occurs in passive and the existence is optional.

Furthermore, the confusion between the inchoative use of get and get passive construction is often found; therefore, it is crucial to highlight the differences. The inchoative always use adjectival predicative. For example, the police got mad. As a matter of fact, the confusion is also caused by the similar form of the adjective and past participle (Chappell 1983: 423). For example, her teeth got brushed. The example shows that this sentence can be interpreted as get passive and adjectival predicate because of the form of brushed which is similar to adjective and past participle. Despite this similarity, an adverbial test can be applied to distinguish two forms. The sentence will be interpreted as an adjectival predicate when an adverb, specifically an adverb of degree and 
intensity, can be inserted in the sentence (Chappell $1980 \mathrm{p} \mathrm{423).} \mathrm{For} \mathrm{example,} \mathrm{her} \mathrm{teeth} \mathrm{got} \mathrm{very} \mathrm{well} \mathrm{brushed.} \mathrm{In} \mathrm{doing} \mathrm{so,} \mathrm{get}$ passive can be easily distinguished because it cannot take an adverb.

Another problem of get form which often emerges confusion with get passive is the implicit existence of the second person which leads to forming get likes a reflexive form (Chappel 1980: 423). For example, the professor got retired. In this example, got retired does not take any by phrase because it is an adjective predicate. Due to the inexistence of this phrase, people are often confused and interpret it as get passive because it has the same form as get passive. However, by phrase test can be applied to figure out whether the form is a get passive or adjectival predicate. It is due to the fact that adjective predicative does not take by phrase with the sentence.

In addition to analyzing the semantic structure of get passive, it is important to highlight the divisions of be passive and get passive. Be passive is divided into dynamic and static (Granger 1983: 196). Granger claimed that a static event refers to an existing event that is unchanging, nonstop, and consistent all the way through its duration. The dynamic event, on the contrary, alludes to the situation which may take place momentarily or continue but may undergo several temporal forms and it may or may not in the control of an agent. She made a crystal-clear explanation that a situation is regarded as a process if it is expanded over time. It is an event if it momentarily exists and it is an action if it is in the control of an agent (Lyons cited in Granger 1983: 196).

Unlike be passive, get passive is segregated into the adversative and beneficial nature of the event (Chappell 1980: 417). It is due to the fact that the involvement of the subject as the cause of an event is different in each get passive form. The subject can play a role to control, initiate and responsible for an event (Chappell 1980: 424). Lakoff is in line with Chappell and explicates that the agent plays a control in the be passive whereas the patient gains the control in the get passive (cited in Fox \& Hopper 1994: 119).

The first type of adversative passive is called non-reflexive adversative get-passive. The function of this get passive is to express an event in which the subject is not an innocent victim of a circumstance (Chappell 1980: 425). For example, the thief got arrested this morning after being chased for one month. Get passive can be applied in the sentence because the thief is not the victim but a doer of his bad action and deserves to get arrested. In comparison to get passive, the sentence, such as the civil societies were shot during the war between the military defenses and the enemy, clearly shows that only be passive can be used because the subject which is civil societies are the innocent victims.

Another semantic meaning is applied to restrict the use of non-reflexive adversative get passive. Get passive cannot be used to express a sentence that indicates a subject who is controlled by another person and the subject has to do the desire of the agent (Chappell 1980: 423). For example, the robber was ordered to put the gun by the police. Be passive is better used than get passive because the robber is under the control of the police. Interestingly, in the story of the crucifixion, be and get can be used for a different interpretation. If crucifixion is regarded as predestined nature then be is best used. It is due to the fact that Christ is seen as gaining no option in the circumstance. However, get can be used if the speaker wants to imply that Christ could have done something to inhibit the event of his crucifixion. Nevertheless, this may still mean negative implications if it is spoken by the opponents of Christ, such as Judas, Pilates, etc. Therefore, the use of get may be restricted to the follower of Christ but unrestricted to the opponents of Him. It is thus true to say Christ got crucified or Christ was crucified for the opponents of Christ. Yet, for the followers of Christ, it is only true to say Christ was crucified (Chappell 1980: 426-27).

In contrast to the context of crucifixion, there is another example where get passive is used to indicate that the subject could have escaped from the unfavorable situation and the speaker has empathy for the subject (Chappell 1980: 428). For example, my friend's car got stolen every time he went on holiday. It is obvious that get passive is not linked to blame, contempt, or disapproval in this context.

The second type of get passive is reflexive adversative get passive. The unfavorable events of this passive are caused by the subject (Chappell 1980: 430). For example, he got himself fined by the police because he was driving without an Australian driver's license. It is evident in the example that the unfortunate event is caused by the fault of the subject which triggers the second person, who is the police, to fine. The example shows that the unfortunate event is the result of intentional causation attributed to the subject. Chappell, however, also notes another example which does not mean the subject wants to perform the unfavorable event. For example, she wanted to save her baby but accidentally got herself crushed by the car. The performed behavior implies a similar misfortune effect as other sentences which denote intentional causation effect but the difference lies in the unwanted motivation. The author clearly emphasized that the component of this passive does not include the subject's want which triggers the agent to act, but the unfavorable events exist because the subject has done something to prompt the agent to perform the unfavorable event.

Another adversative get passive is called the adversative get passive with an inanimate subject. This type of passive does not have any reflexive form and the affected entity of this get passive is the animate entity, such as a person who has a direct relationship

Page | 43 
to the inanimate subject (Chappell 1980: 440). For example, Marry's dog got killed when she went on holiday. The direct relationship shows that the owner of the thing is responsible for could have stopped the misfortune event. In the case of Mary's dog, Marry was supposed to give it to her relative rather than letting the dog stayed alone. Thus, the misfortune event can be prevented. However, if the person should not be expected for responding to the misfortune event of the inanimate entity then be passive can be used (Chappell 1980: 442). For example, the man was released by the police because he did not know the case.

Similar to adversative get passive, beneficial get passive also has non-reflexive beneficial get-passive and reflexive get passive. The non-reflexive beneficial get-passive implies that the subject wants an event to occur and in order to achieve it, the subject also makes efforts that encourage others to do it (Chappell 1980: 436). For example, Lucille got accepted into her new job. In this state of affairs, Lucille really wants to get the job so she applied and did her best in the interview to make the interviewer passed her in the selection. Nevertheless, Chappell (1986: 415) also points out that the action of the subject may not become the main reason for the agent to accomplish the desire of the subject. There may be other reasons which are not provoked by the subject's desire. Another possible reason for Lucille got accepted in her new job, for example, maybe due to the fact that Lucille was the only applicant who attended the interview so the interviewer had to pass her. This example reason illustrates that the desire of the subject is not the only reason which prompts the event to occur.

In addition to that, non-reflexive beneficial get passive also plays an important role to demonstrate the speaker's displeasure towards others' good fortune (Chappell 1980: 437). The speaker uses get to purely wish luck towards the subject. Chappell proposes the examples in which get are used to express the criticism towards the success of political figures. For example, Napoleon got crowned Emperor. In the same example, be passive can also be used but it tends to denote neutral meaning, such as Napoleon was crowned (Chappell 1980: 437). It is obvious in this context that get passive can denote negative meaning but be passive is used to mean neutral meaning.

Furthermore, non-reflexive beneficial get passive can be used if the speaker has an intended purpose of the expected event (Chappell 1980: 436). For example, She got awarded $\$ 10.000$ after winning the photography competition. It is clear that the subject has the purpose to join the competition because she can get the prize. Nonetheless, if the subject does not have any hidden intention, be passive should be used. For example, Mother Teresa was awarded Nobel Prize. In this example, Mother Teresa never had any purpose of gaining a Nobel prize to do her social activities, she did the activities because of her passion and motivation to help unfortunate people.

The second type of beneficial get passive is the reflexive beneficial get passive in which subject really wants desired event to take place. In fact, the desired event or action is not specified in the sentence (Chappell 1980: 438). The man got himself selected. It is clear in the example that there is no further specific information about the event which makes the man being selected. However, if the event is specified then be passive is used. For example, the man was selected for the Australian leadership scholarship. In comparison to the previous example, the event of be passive is more obvious and specific than in get passive.

The last type of beneficial get passive is beneficial get passive with an inanimate subject. Similar to adversative get passive with the inanimate subject, the affected entity of this get passive is the person or owner of the entity which acts as the subject of the sentence. The occurrence of the event is triggered by the desire of the owner to make it real because it is for the benefit of the person or owner (Chappell 1980: 442). For example, Mary's laptop got installed with new anti-virus protection. The example illustrates that Marry wants the laptop got installed and Marry receives the benefit of the conducted action. However, if the owner of the entity is not obvious enough then be passive is used. For example, the laptop was installed with new anti-virus protection.

\section{Conclusion}

In conclusion, the paper has investigated English be passive and get passive to answer the question of whether get passive can replace be passive. As matter of fact, get passive cannot replace be passive because of several reasons. From a semantic structure point of view, firstly the stative verbs, such as emotion and thought cannot be addressed with get passive. Secondly, get passive does not go well with the verbs "creation". In addition to the semantic structure, the other six types of get passives show no indication that get passive can replace the function of be passive in some contexts. For example, in the non-reflexive adversative, get passive cannot express the subject of an innocent victim of a circumstance. Besides that, get passive cannot be used to express a sentence that indicates a subject who is controlled by another person and the subject has to do the desire of the agent. The second type where it shows get passive cannot replace be passive is in the reflexive adversative get passive. In this get passive, get is used to express the unfavorable events which are caused by the subject rather than be passive. The third type of adversative get passive which proves that get passive cannot replace be passive is adversative get passive with an inanimate subject. In this get 
passive, get can only be used if the owner is responsible for the entity and could have prevented it, whereas if the owner is not expected to responsible for it then be passive is used.

In addition to adversative get passive, beneficial get passive also implies that get passive cannot replace be passive because in the non-reflexive beneficial get-passive, get plays an important role to express subject's effort to encourage the agent to do the desired event, demonstrate speaker's displeasure towards others' good fortune and express an intended purpose of the expected event. Moreover, the reflexive beneficial get passive also explicates the function of get passive to express the subject's desired event to take place. Furthermore, the beneficial get passive with an inanimate subject also explains the use of get to denote the person or owner of the entity as the affected one. After proposing all these different uses of get passive, it can be argued that get cannot be claimed to replace be passive because it denotes different meanings and get passive has restricted uses. If be passive is used in the context of get passive then it will shift the meanings.

\section{References}

[1] Börjars, K. \& Burridge, K. (2010). Introducing English Grammar. Hodder Education. London

[2] Culicover, P. (2009). Natural language syntax. Oxford University Press. Oxford

[3] Chappell, H. (1980). Is the get passive adversative?. International Journal of Human Communication, 13 (3), 411-452.

[4] Chappel, H. (1986). The get passive revisited: a reply to Sussex (1982). Paper in Linguistics 19 (3), 413-424.

[5] Fink, A. (2014). Conducting Research Literature Reviews From The Internet to Paper. SAGE Publication. London

[6] Fox, B. \& Hopper, J.P.(1994). Voice form and function. John Benjamins. Amsterdam.

[7] Granger, S. (1983). The be+ past participle construction in spoken English with special emphasis on the passive. Elsevier Science Publisher B.V. Netherlands.

[8] Hatcher, A.G. (1949). To get/be invited. Modern Language Notes 64 (7), 433-446.

[9] Kumar, R. (2011). Research Methodology A Step by Step Guide for Beginners. SAGE Publication. London.

[10] Martins, F.S., da Cunha, J.A.C, Serra, F.A.R. (2018). Secondary Data in Research - Uses and Opportunities. PODIUM Sport, Leisure and Tourism Review (7).

[11] Mitkovska, L. \& Bužarovska, E. (2011). An Alternative Analysis of The English Get-Past Participle Constructions: Is Get All That Passive? Journal of English Linguistics XX (X), 1-20.

[12] Smith, E. (2008). Using Secondary Data in Educational and Social Research. Open University Press. Berkshire, England.

[13] Smith, E. (2010). Pitfalls and Promises: The Use of Secondary Data Analysis in Educational Research. British Journal of Educational Studies 56

(3), 323-339.

[14] Sussex, R. (1982). A note on the gets passive construction. Australian Journal of Linguistics 2, 83-95.

[15] Villalibre, E. C. (2015). Is The Get-Passive Really That Adversative? Miscelánea: A Journal of English and American Studies (51), 13-30. 